\title{
Prediction of Pesticide Behavior in Paddy Field by Water Balance on the Water Management Using Pesticide Paddy Field Model (PADDY)
}

\author{
Keiya INAO, ${ }^{*, *}$ Yasuo IshII, Yuso Kobara and Yasuo KITAMURA ${ }^{\dagger}$ \\ National Institute of Agro-Environmental Sciences, Ministry of Agriculture, Forestry and Fisheries, \\ Kannondai, Tsukuba, Ibaraki 305-8604, Japan \\ + Agricultural Chemicals Inspection Station, Ministry of Agriculture, Forestry and Fisheries, \\ Suzuki-cyo, Kodaira, Tokyo 187-0011, Japan
}

(Received August 25, 2000 ; Accepted January 31, 2001)

\begin{abstract}
The improved version of the pesticide paddy field model (PADDY) was evaluated for the prediction of pesticide concentrations in water and soil considering water balance on the water management. Field studies under the two different conditions on the water management practices, continuous irrigation and drainage, and water holding management that regulate drainage during the experimental periods, were performed to validate the improved model using molinate and simetryne. For both pesticides, concentrations in paddy water were the same level during the first day after the application on both fields. After second day, pesticide concentrations on the field for continuous irrigation and drainage were lower than those on the field of water holding management. Good fits between model predictions and field observations were obtained for the two pesticides by considering the water management and hydrological condition.
\end{abstract}

Key words: environmental fate, pesticides, paddy, water balance, simulation model.

\section{INTRODUCTION}

Recently, there has been growing concern about the risk related to the use of pesticide. Pesticides are intentionally applied to agricultural lands, and there is a possibility that a part of pesticides transfers to public water areas such as rivers and lakes. In Japan, over 50\% of agricultural lands are paddy fields, and pesticides are used extensively in paddy fields to control pests and weeds that affect rice plants. Especially, herbicides used in paddy fields are detected often in river water from May to July after the pesticides application. ${ }^{1,2)}$

In the previous paper, ${ }^{3)}$ we validated the pesticide paddy field model (PADDY) for predicting pesticide concentrations and pesticide runoff amounts. Accurate prediction of pesticide runoff loss is required to estimate the environmental concentration of pesticides in public water areas. In the previous version of PADDY, how-

\footnotetext{
* To whom correspondence should be addressed.

* Present address: Agricultural Chemicals Control Office, Water Environment Department, Environmental Management Bureau, Ministry of the Environment, Kasumigaseki, Chiyoda-ku, Tokyo 100-8975, Japan.
}

ever, steady state was applied in water balance for the water management in paddy field and weather conditions were not considered. Therefore, under the outdoor conditions where outflow rate of paddy water changes by weather and water management, the model cannot accurately predict pesticide runoff.

In this study, to estimate the behavior of pesticides more accurately, we modified the PADDY for calculation of water balance in paddy field with site-specific environmental conditions. We also performed paddy field experiments under the different conditions on water management to validate the model, and calculated values by the modified model were compared with experimental results of measured concentrations.

\section{THEORY, MATERIALS AND METHODS}

\section{Water Balance in Paddy Field}

The water movement processes are inflow (irrigation), precipitation, evaporation, transpiration, outflow (overflow), and both vertical and horizontal percolation as shown in Fig. 1. The water balance equation in paddy field can be expressed as follows: 


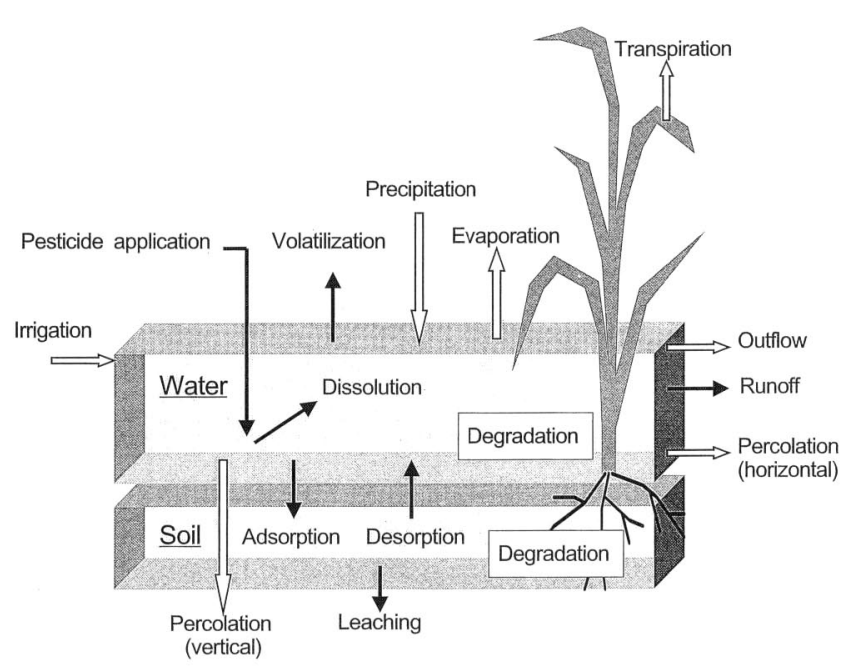

Fig. 1 Water balance and pesticide behavior in paddy field. $\rightarrow$ : pesticide transport, $\triangleq$ : water movement.

$$
A \frac{d h}{d t}=Q_{i n}-Q_{o u t}+A(P-E-T)-q_{v}-q_{h}
$$

Where $A$ is area of paddy field $\left(\mathrm{m}^{2}\right), h$ is water depth (m) at time $t, Q_{i n}$ is irrigation rate $\left(\mathrm{m}^{3} / \mathrm{day}\right), Q_{\text {out }}$ is outflow rate $\left(\mathrm{m}^{3} /\right.$ day $), P$ is precipitation $(\mathrm{m} /$ day $), E$ is evaporation rate $(\mathrm{m} /$ day $), T$ is transpiration rate $(\mathrm{m} /$ day $), q_{v}$ is vertical percolation rate $\left(\mathrm{m}^{3} /\right.$ day), and $q_{h}$ is horizontal percolation rate $\left(\mathrm{m}^{3} /\right.$ day). If $h$ is smaller than height of outlet $\left(h_{\text {out }}\right), Q_{\text {out }}$ is zero. In case $h$ is higher than $h_{\text {out }}$, outflow is generated. Under these conditions, this equation can be solved by finite difference method (backward difference approximation) with daily inflow, rainfall, evaporation, transpiration, and both vertical and horizontal percolation data. As the results, $h$ and $Q_{\text {out }}$ are obtained as a function of time $t$.

\section{Mass Balance of Pesticides in Paddy Field}

Figure 1 shows water balance and the pesticide transport processes in paddy field for PADDY. In this model, the process of pesticide uptake by plants was not considered. If pesticide concentration in irrigation water is equal to zero, the mass balance equations on the surface of paddy field are given below :

For the water compartment,

$$
\begin{aligned}
A h \frac{d C_{w}}{d t}= & A h k_{s}\left(C_{w s}-C_{w}\right)-Q_{o u t} C_{w}-\left(q_{v}+q_{h}\right) C_{w} \\
& -M k_{d e s}\left(K_{f} C_{w}^{1 / n}-C_{s}\right)-K_{L} A C_{w}-A h k_{d w} C_{w}
\end{aligned}
$$

For the soil solid compartment,

$$
M \frac{d C_{s}}{d t}=M k_{d e s}\left(K_{f} C_{w}^{1 / n}-C_{s}\right)-M k_{d s} C_{s}
$$

Where $C_{w}$ is pesticide concentration in water $(\mathrm{mg} / \mathrm{l}), k_{s}$ is dissolution rate constant ( $1 /$ day $), C_{w s}$ is water solubility of pesticide $(\mathrm{mg} / \mathrm{l}), M$ is weight of surface soil solid $(\mathrm{kg}), k_{\text {des }}$ is desorption rate constant $(1 /$ day $), K_{f}$ is Freundlich adsorption coefficient $(1 / \mathrm{kg}), 1 / n$ is Freund- lich exponent, $C_{s}$ is pesticide concentration in soil solid $(\mathrm{mg} / \mathrm{kg}), K_{L}$ is volatilization rate $(\mathrm{m} /$ day $)$, and $k_{d w}$ and $k_{d s}$ is first-order degradation rate constant in paddy water and soil (1/day), respectively.

For the dissolution of the granule formulation,

$$
\frac{d W}{d t}=-A h k_{s}\left(C_{w s}-C_{w}\right)
$$

Where $W$ is amount of pesticide in the granule formulation (mg). When dissolution of the pesticide from the granule is completed ( $W=0$ ), $k_{s}$ is set to zero in equations 2 and 4 . In the previous version of PADDY, hydrological and management condition was not considered, and water depth $(h)$ and outflow rate $\left(Q_{\text {out }}\right)$ were handled as constant values. In the modified version of PADDY, $h$ and $Q_{o u t}$ can be calculated by Equation 1 as a function of time $t$, and these values and input parameters are substituted in Equations 2-4, pesticide concentrations in water and soil can be obtained by numerical solution technique (Runge-Kutta-Gill method).

\section{Model Validation}

\subsection{Pesticides}

Molinate ( $S$-ethyl hexahydro- $1 H$-azepine-1-carbothioate) and simetryne [4,6-bis(ethylamino)-2-methylthio-1,3,5-triazine] were used to validate the modified version of PADDY. The formulated product used for experiment was the Mamet ${ }^{\circledR}$ SM One Kiro Granule (24.0\% molinate, $4.5 \%$ simetryne and $2.4 \%$ MCPB ethyl). Table 1 shows physicochemical properties, equilibrium

\begin{tabular}{|c|c|c|}
\hline Parameter & Molinate & Simetryne \\
\hline \multicolumn{3}{|l|}{ Physicochemical properties } \\
\hline molecular weight $(\mathrm{g} / \mathrm{mol})$ & 187.3 & 213.3 \\
\hline water solubility $\left(C_{w s}, \mathrm{mg} / \mathrm{l}\right)$ & $800\left(20^{\circ} \mathrm{C}\right)$ & $450\left(20^{\circ} \mathrm{C}\right)$ \\
\hline vapor pressure $(\mathrm{mm} \mathrm{Hg})$ & $\begin{array}{l}5.7 \times 10^{-3} \\
\left(25^{\circ} \mathrm{C}\right)\end{array}$ & $\begin{array}{l}7.1 \times 10^{-7} \\
\left(20^{\circ} \mathrm{C}\right)\end{array}$ \\
\hline \multicolumn{3}{|l|}{ Equilibrium constants } \\
\hline Henry's constant (-) & $7.2 \times 10^{-5}$ a) & $1.8 \times 10^{-8}$ a) \\
\hline adsorption coefficient $\left(K_{f}, 1 / \mathrm{kg}\right)$ & $2.2^{\mathrm{b})}$ & $3.0^{\mathrm{b})}$ \\
\hline [Freundlich exponent $(1 / n)]$ & 1 & 1 \\
\hline \multicolumn{3}{|l|}{ Rate constants } \\
\hline dissolution $\left(k_{s}, 1 /\right.$ day $)$ & $9.6 \times 10^{-3 \mathrm{c})}$ & $3.9 \times 10^{-3 \mathrm{cl}}$ \\
\hline desorption $\left(k_{\text {des }}, 1 /\right.$ day $)$ & $2.9 \times 10^{-1 c)}$ & $1.5 \times 10^{-1 \mathrm{c})}$ \\
\hline volatilization $\left(K_{L}, \mathrm{~m} /\right.$ day $)$ & $1.6 \times 10^{-2 \mathrm{~d})}$ & $\left.3.8 \times 10^{-6} \mathrm{~d}\right)$ \\
\hline $\begin{array}{l}\text { degradation in water } \\
\left(k_{d w}, 1 / \text { day }\right)\end{array}$ & $1.9 \times 10^{-2 \mathrm{c})}$ & $\left.4.7 \times 10^{-3} \mathrm{c}\right)$ \\
\hline degradation in soil $\left(k_{d s}, 1 /\right.$ day $)$ & $\left.1.7 \times 10^{-2} \mathrm{e}\right)$ & $\left.1.4 \times 10^{-2} \mathrm{e}\right)$ \\
\hline
\end{tabular}
constants, and rate constants for molinate and simetryne, which were measured and estimated values. ${ }^{3)}$

Table 1 Model input parameters of molinate and simetryne.

a) Calculated by the dilling equation (reference 4 ).

b) Obtained from reference 5 . Organic carbon content in soil is $2 \%$. c) Measured value (reference 3). d) Calculated by the Liss \& Slater method (reference 6). e) Obtained from references 7 and 8 . 


\subsection{Field experiment}

To validate the modified PADDY, a field experiment was carried out on paddy fields in National Institute of Agro-Environmental Sciences. The layout of paddy fields for the experiment is shown in Fig. 2. Paddy fields were surrounded by concrete frame to maintain flooded condition. Irrigation water was supplied by pipeline and an irrigation tap was installed on each field plot. The outlet, which controls water depth, was also assembled. The soil texture is light clay (clay $47 \%$, silt $19 \%$, sand $34 \%$ ) having $2 \%$ organic carbon and $\mathrm{pH}$ of $5.2 /$ $\mathrm{H}_{2} \mathrm{O}$. The experiment was conducted between July 1st and August 1st, 1996. The average temperature was $24.4^{\circ} \mathrm{C}\left(16.2-35.1^{\circ} \mathrm{C}\right)$, and $\mathrm{pH}$ in paddy water ranged from 6.6 to 7.9 .

At 26 days after transplanting of rice plant (July 1st, 1996), the Mamet SM granule was applied uniformly by hand at a rate of $10 \mathrm{~kg} / \mathrm{ha}$ (molinate $2400 \mathrm{~g} / \mathrm{ha}$, simetryne $450 \mathrm{~g} / \mathrm{ha}$ as active ingredient) under the flooded conditions. The experiments were performed under two different conditions on water management. One is water-holding management, which means water depth was kept about $4 \mathrm{~cm}$ by supplying irrigation corresponding to water requirement in depth without excess water (Field 1). The other management is continuous irrigation, which is the outlet of field plot was adjusted so that maximum water level was $4 \mathrm{~cm}$ and irrigation water was supplied at a fixed flow rate (Field 2).

\subsection{Sampling}

At various intervals of $3 \mathrm{hr}, 6 \mathrm{hr}, 1,2,4,7,14,22$, and 31 days after the application, water samples were collected at $1-2 \mathrm{~cm}$ depth in paddy water by a water collecting equipment composed of a manual suction pump and a glass bottle connected with a Teflon tube. A compos-



Fig. 2 Layout of the two model paddy fields experiment for sampling site.

$O$ : sampling site of paddy water and measurement site of water depth, $\bullet$ : sampling site of soil, $\triangle$ : measurement site of receded water depth. Arrows $(\rightarrow)$ indicate water movement. ite water sample from each field plot of five spots was analyzed for pesticide concentrations in paddy water. Soil samples were taken from two sites of the Field 1 at intervals of $1,4,7,14$, and 31 days after the application as shown in Fig. 2. The samples were collected $5.0 \mathrm{~cm}$ deep with stainless steel cylinder $(20 \times 5 \mathrm{~cm}$ I.D.) and divided into two layers $(0-2.5 \mathrm{~cm}$ and $2.5-5.0 \mathrm{~cm}$ depth) and mixed for each layer and analyzed individually.

\subsection{Observation of hydrological condition}

Water depth, volume of irrigation water, and the fall in paddy water depth which resulted from vertical percolation and evapotranspiration were measured during the experimental periods. Polyvinyl chloride pipes $(30 \times 20$ $\mathrm{cm}$ I.D.) were inserted into the soil of about $20 \mathrm{~cm}$ deep at two sites in the Field 1 (see Fig. 2). The falls in paddy water depth in a day were determined by measuring the differences of the water levels in these pipes during the day. Daily vertical percolation rate was calculated by subtracting daily evapotranspiration rate from the fall in paddy water depth in a day. Daily horizontal percolation rate was calculated by subtracting both daily evapotranspiration and vertical percolation rate from the daily difference of water depth in the field. Daily rainfall and pan evaporation data were obtained from meteorological observatory of the Institute. . In general, evaporation amount from water surface is relatively large in the initial growth stage of rice plant, however, it decreases with the flourish of the rice. On the other hand, transpiration from rice plant depends on surface area of the rice plant, and it increases with the plant growth. ${ }^{9)}$ However, it is reported that evapotranspiration ranged from 0.96 to 1.22 times as much as pan evaporation through the growing period. ${ }^{10)}$ Therefore, evapotranspiration was assumed to be equal to pan evaporation from meteorological observatory data.

\subsection{Pesticide analysis}

Water samples (50 and/or $200 \mathrm{ml}$ ) were passed through a solid phase extraction cartridge (WATERS Sep-Pak PS-2), and the cartridge was eluted with ethyl acetate $(10 \mathrm{ml})$. Then the eluate was concentrated in a rotary evaporator at $40^{\circ} \mathrm{C}$ to about $1 \mathrm{ml}$ and dried up gently by $\mathrm{N}_{2}$ gas purging and dissolved in acetone. Soil samples $(25 \mathrm{~g})$ were extracted for two times with $200 \mathrm{ml}$ of a mixture of water and acetone $(1: 3, \mathrm{v} / \mathrm{v})$ by shaker. The combined extract was concentrated until the acetone was removed. The residue was passed through a SepPak PS-2 cartridge, and the cartridge was eluted with ethyl acetate $(10 \mathrm{ml})$. Then the eluate was dried up and dissolved in $10 \%$ acetone in hexane. Clean-up was performed with glass columns $(30 \mathrm{~cm} \times 8 \mathrm{~mm} \quad$ I.D. $)$ packed with anhydrous $\mathrm{Na}_{2} \mathrm{SO}_{4}(1.5 \mathrm{~g})$ layer overlaid on silica gel $(630 \mathrm{mg})$ layer. ${ }^{11)}$ Silica gel was activated overnight at $130^{\circ} \mathrm{C}$, and cooled in a desiccator, and deactivated with $4 \%$ water. The column was rinsed with $n$-hexane $(10 \mathrm{ml})$ just before use. The soil extracts were 
placed on the top of the column. Then the column was eluted with $10 \mathrm{ml}$ of $10 \%$ acetone in hexane. The eluate was dried up and dissolved in acetone with abovementioned method. Pesticide residues were determined using a GC-FTD (Shimadzu GC-17A) with a column of DB-5 $(0.32 \mathrm{~mm}$ I.D. $\times 30 \mathrm{~m})$. The limits of determination for two herbicides in water and soil by the above method were $0.1 \mu \mathrm{g} / 1$ and $1 \mu \mathrm{g} / \mathrm{kg}$, respectively. The recovering ratio of each pesticide was $88-94 \%$ for water samples and $89-93 \%$ for soil samples. Duplicate analysis of pesticides was performed.

\section{RESULTS AND DISCUSSION}

\section{Field Experiment}

\subsection{Hydrological condition}

Conditions of the experimental paddy fields are shown in Table 2. The average vertical and horizontal percolation rates of water during the experimental period were 0.4 and $0.3 \mathrm{~cm} /$ day, respectively. For continuous irrigation method on the Field 2, water was supplied at an average rate of $0.92 \mathrm{~m}^{3} /$ day, which was equivalent to 2.3 $\mathrm{cm} /$ day increase in the water level. Precipitation (observed), discharge (simulated) and water depth (observed and simulated) are shown in Fig. 3. On the Field 2, the fraction of discharged water over total volume of paddy water was about $30 \%$ per day at no rainfall condition. At 7-9 days after the application, daily precipitation exceeded $20 \mathrm{~mm} /$ day, and overflow was also generated on the Field 1 by water holding management. Simulated water depth on the Field 1 increased with precipitation. Calculated water depth by modified PADDY agreed well with the trend of measured values. The model prediction reflected observed hydrological condition.

\subsection{Measured concentrations of pesticides in paddy water}

Figure 4 shows the measured changes of two pesticide concentrations in paddy water. Pesticide concentrations on the Field 1 increased immediately after the applica-

Table 2 Conditions of experimental paddy field.

\begin{tabular}{lll}
\hline \multirow{2}{*}{ Parameter } & \multicolumn{2}{c}{ Values } \\
\cline { 2 - 3 } & Field 1 & Field 2 \\
\hline Area of paddy field $\left(A, \mathrm{~m}^{2}\right)$ & 40 & 40 \\
Height of outlet $\left(h_{\text {out }}, \mathrm{m}\right)$ & 0.06 & 0.043 \\
Initial water depth $(\mathrm{m})$ & 0.036 & 0.043 \\
Percolation rate & & \\
$\quad$ Vertical $\left(q_{v} \mathrm{~m}^{3} / \mathrm{day}\right)$ & $0.16^{\mathrm{a})}$ & $0.16^{\mathrm{a})}$ \\
$\quad$ Horizontal $\left(q_{h}, \mathrm{~m}^{3} / \mathrm{day}\right)$ & $0.12^{\mathrm{a})}$ & $0.12^{\mathrm{a})}$ \\
Irrigation rate $\left(Q_{i n}, \mathrm{~m}^{3} /\right.$ day $)$ & $-\mathrm{b})$ & $0.92^{\mathrm{a})}$ \\
Soil bulk density $\left(\mathrm{g} / \mathrm{cm}^{3}\right)$ & 0.9 & 0.9 \\
Porosity & 0.4 & 0.4 \\
\hline
\end{tabular}

a) Average value during the experimental periods. b) Water depth was kept about $4 \mathrm{~cm}$ to supplement irrigation water corresponding to water requirement in depth.


Fig. 3 Changes in environmental conditions. (a) daily rainfall recorded at NIAES; (b) discharge simulated by PADDY; (c) water depth.
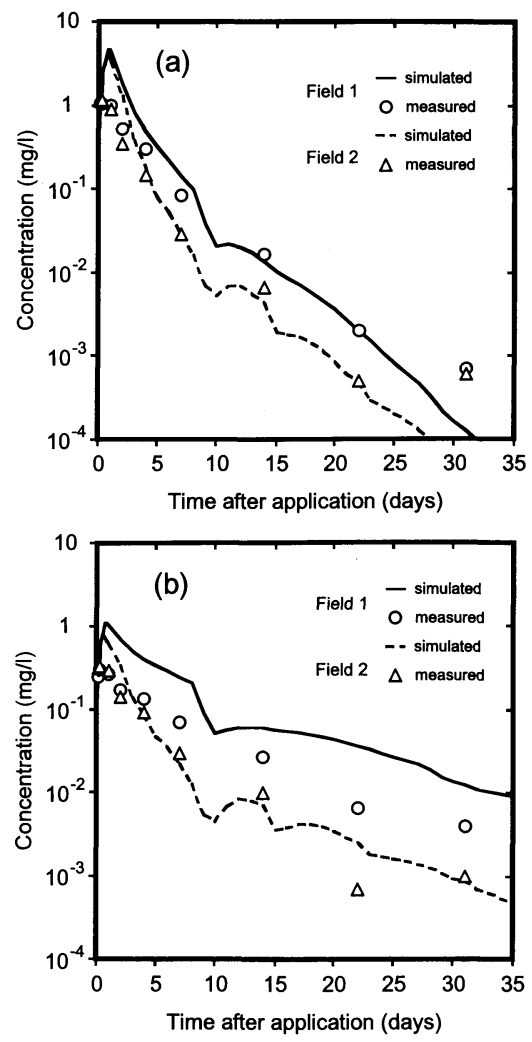

Fig. 4 Comparison between simulated and measured pesticide concentrations in paddy water.

(a) Molinate; (b) Simetryne. 
tion, and reached the maximum around 3-6 hr after the application (molinate: $1.05 \mathrm{mg} / \mathrm{l}$ at $3 \mathrm{hr}$, simetryne: 0.30 $\mathrm{mg} / 1$ at $6 \mathrm{hr}$ ). Then pesticide concentrations declined rapidly with time, and were 0.7 and $4 \mu \mathrm{g} / 1$ for molinate and simetryne at day 31 , respectively. Pesticide concentrations on the Field 2 were the same level as those on the Field 1 during the first day after the application because dissolution of two pesticides in paddy water from the granule was not released. After second day, however, pesticide concentrations on the Field 2 were lower than those on the Field 1. It is assumed that the main reason for the difference of pesticide concentration was due to runoff loss of pesticide with continuous irrigation.

\subsection{Measured concentrations of pesticides in soil}

The measured pesticide concentration profiles in soil on the Field 1 are shown in Fig. 5 . In $0-2.5 \mathrm{~cm}$ soil layer, pesticide concentrations increased immediately after the application, and peaked around 4 to 7 days (molinate: $1.42 \mathrm{mg} / \mathrm{kg}$ at 4 days, simetryne: $0.59 \mathrm{mg} / \mathrm{kg}$ at 7 days), then declined gradually. In $2.5-5.0 \mathrm{~cm}$ depth, pesticide concentrations increased gradually and reached the maximum (molinate: $0.35 \mathrm{mg} / \mathrm{kg}$, simetryne: $0.057 \mathrm{mg} / \mathrm{kg}$ ) at 14 days after the application, then decreased slowly with the lapse of time. The time lag of the maximum concentrations in two different layers was probably the result of the pesticide percolation through paddy soil. For example, cumulative depth of percolation was $2.4 \mathrm{~cm}$ at 6 th day after the pesticide application and $4.8 \mathrm{~cm}$ at 12 th day after the application, which correspond to the peak concentrations of pesticides in the soil for those two layers.

\section{Mass Distribution in Paddy Field}

Mass distribution of pesticides was calculated from measured concentrations in paddy water and soil on the Field 1 (Table 3 ). About 16\% of initially applied molinate was distributed in paddy water at $3 \mathrm{hr}$ after the application. Four days later, as much as $5 \%$ was found and after 22 days, less $0.1 \%$ was in water. About $23 \%$ of applied simetryne was distributed in water at $6 \mathrm{hr}$ after


Fig. 5 Comparison between simulated and measured pesticide concentrations in soil on the Field 1. (a) Molinate; (b) Simetryne.

Table 3 Time course of mass distribution of pesticides in paddy water and soil on the Field 1 .

\begin{tabular}{|c|c|c|c|c|c|c|}
\hline \multirow{3}{*}{$\begin{array}{l}\text { Time after pesticide } \\
\text { application (days) }\end{array}$} & \multicolumn{6}{|c|}{$\%$ of initial pesticides applied } \\
\hline & \multicolumn{3}{|c|}{ Molinate } & \multicolumn{3}{|c|}{ Simetryne } \\
\hline & Water ${ }^{a)}$ & $\begin{array}{c}\text { Soil }^{\mathrm{b})} \\
(0-2.5 \mathrm{~cm})\end{array}$ & $\begin{array}{c}\text { Soil }{ }^{\mathrm{b})} \\
(2.5-5 \mathrm{~cm})\end{array}$ & Water ${ }^{a)}$ & $\begin{array}{c}\text { Soil }{ }^{\mathrm{b})} \\
(0-2.5 \mathrm{~cm})\end{array}$ & $\begin{array}{c}\text { Soil }^{\mathrm{b})} \\
(2.5-5 \mathrm{~cm})\end{array}$ \\
\hline $3 \mathrm{hr}$ & 15.8 & $-c)$ & - & 19.5 & - & - \\
\hline $6 \mathrm{hr}$ & 15.2 & - & - & 23.2 & - & - \\
\hline 1 & 11.1 & 8.0 & 0.1 & 15.8 & 20.1 & 0.6 \\
\hline 2 & 6.7 & - & - & 11.6 & - & - \\
\hline 4 & 5.2 & 13.3 & 1.0 & 12.3 & 24.7 & 0.9 \\
\hline 7 & 1.6 & 7.3 & 2.1 & 6.8 & 15.7 & 1.1 \\
\hline 14 & 0.2 & 4.1 & 3.2 & 1.3 & 16.1 & 2.9 \\
\hline 22 & $<0.1$ & - & - & 0.6 & - & - \\
\hline 31 & $<0.1$ & 2.5 & 2.1 & 0.2 & 12.6 & 1.2 \\
\hline
\end{tabular}

These values were calculated using measured concentrations in experimental paddy field as percent of molinate $(2400 \mathrm{~g} / \mathrm{ha})$ and simetryne $(450 \mathrm{~g} / \mathrm{ha})$ applied. ${ }^{\text {a) }}$ Volume of paddy water $\times$ pesticide concentration in paddy water $\div$ applied amount of pesticide. b) Volume of soil $\times$ soil bulk density $\times$ pesticide concentration in soil $\div$ applied amount of pesticide. ${ }^{\text {c) }}$ - : Not measured. 
the application, however, the dissipation of simetryne was slower than that of molinate.

The difference of dissipation pattern reflects the fact that volatilization rate of molinate is much larger than simetryne. Mass distribution of simetryne in soil was higher than that of molinate, reflecting different adsorption coefficients (Table 1).

\section{Validation of Modified PADDY}

Validation of the modified PADDY was performed using the result of field experiment as shown in Figs. 4 and 5. The model input data for both pesticide parameters and environmental conditions considering water balance in paddy fields are listed on Tables 1 and 2 . The PADDY generally tended to overestimate pesticide concentrations in paddy water. Simulated pesticide concentrations in paddy water were about five times as much as measured concentrations within 2 days after the application. In the model, paddy water compartment was assumed to be completely mixed conditions, and the diffusion between upper and lower layer in paddy water was not considered. Therefore, simulated pesticide concentrations may not reflect such process in actual paddy water. On the other hand, good fits between simulated and observed concentrations in both $0-2.5$ and 2.5-5.0 $\mathrm{cm}$ soil layers were obtained for the two pesticides used.

Around 12 days after the application, there was the rise of pesticide concentrations in water on the simulation curve. It is assumed that rainfall exceed $20 \mathrm{~mm} /$ day caused the rapid dilution of pesticide concentrations in water for 7-9 days after the application, and that afterward, it increased due to desorption of pesticides from soil to paddy water. The modified PADDY is capable of simulating the concentration changes dependent on water balance.


Fig. 6 Runoff amounts and the cumulative runoff of pesticides simulated on the Field 2 by the modified PADDY. (a) Molinate; (b) Simetryne. - : the ratio of cumulative runoff to initial applied of pesticides, daily runoff amount of pesticides.
Runoff loss was also calculated by the modified PADDY over the experimental period of 32 days (Fig. 6 ). On the Field 2 of continuous irrigation and drainage, the cumulative runoff contributions of molinate and simetryne were $40.5 \%$ and $60.4 \%$ of initial applied, respectively. The modified PADDY calculates runoff loss according to the daily discharges as shown in Fig. 3, whereas previous PADDY calculates using average discharge during the simulation period. The modified model can predict runoff loss more accurately under the actual condition of water balance in paddy field.

Generally, for granule formulations used on paddy field as herbicides, the required water-holding period is 3-5 days for both persistence of effect and prevention of environmental load. Ross and Sava ${ }^{12)}$ reported the effect of water-holding periods on reducing herbicide loss to the environment. In this report, for pesticides with low volatility and low degradability, required holding period of 3-5 days was not sufficient to facilitate significant dissipation in order to lower the pesticide concentrations in paddy water. Our estimation was in agreement with this report. From a viewpoint of reducing the environmental load of pesticides due to surface runoff, it is important to regulate the drainage during the water-holding periods. Moreover, after this period, it is necessary to prevent overflow of paddy water on high soluble, low volatile and low degradable pesticides.

\section{ACKNOWLEDGMENTS}

The authors are indebted to Dr. M. Ueji of National Institute of Agro-Environmental Sciences and Dr. H. Watanabe of Tokyo University of Agriculture and Technology for critical comments on the manuscript and to Mrs. K. Matsumoto and T. Kamata in Institute for their assistance in fieldwork.

\section{REFERENCES}

1) S. Maru: Special Bulletin of the Chiba Prefecture Experimental Station, No. 18 (1991) (in Japanese)

2) K. Nakamura: Bulletin of the Saitama Agricultural Experiment Station, No. 46, 61-69 (1993) (in Japanese)

3) K. Inao \& Y. Kitamura: Pestic. Sci. 55, 38 (1999)

4) W. L. Dilling: Environ. Sci. Technol. 11, 405 (1977)

5) ARS Pesticide Properties Database: http://wizard.arsusda. gov.rsml/ppdb.html

6) P. S. Liss \& P. G. Slater: Nature 247, 181 (1974)

7) Y. Imai \& S. Kuwatsuka: J. Pesticide Sci. 7, 487 (1982)

8) T. Izawa, Y. Fujii \& S. Asaka: J. Pesticide Sci. 6, 223 (1981) (in Japanese)

9) F. Adachi, T. Kobata, M. Arimoto \& T. Imaki: Jpn. J. Crop Sci. 64, 509 (1995) (in Japanese)

10) Research group of evapotranspiration: J. Agric. Meteorol. 22, 13 (1967) (in Japanese)

11) Y. Ishii, K. Inao \& Y. Kobara: Proc. Pesticide Residue 20, 34 (1997) (in Japanese)

12) L. J. Ross \& R. J. Sava: J. Environ. Qual. 15, 220 (1986) 


\section{要 約}

水収支を考虑した農薬水田圆場モデル（PADDY）に よる農薬の動態予測

稲生圭哉, 石井康雄, 小原裕三，北村恭朗 水田中での農薬濃度予測モデルとして開発した PADDYについて, 水管理や気象要因等の環境条件から水 田における水収支を計算して農薬動態の予測が可能な数理 モデルの改良を行った. 改良したモデルの検証を行うため, 水田戋場に除草剤モリネートとシメトリンを散布して, 水
田水中及び土壌中の農薬濃度を経時的に測定した．水管理 は水深を一定に保持して, 落水や掛け流しを行わない止水 管理及び一定の流量で用水を流入する掛け流し管理をし て，水収支の異なる条件で試験した，水田水の農薬濃度は 施用後短時間内 $(<1$ 日) で両区での相違はみられなかった が，時間が経つと掛け流し区が止水区に比較してその濃度 は低くなった，改良したモデルは娄場の水管理や降雨等の 気象要因を考慮した水田の水収支を把握することにより, 水収支の異なる条件下における農薬の消長をほぼ予測する ことができた。 